\title{
Şia-Mutezile Gaybet Tartışması (Kadı Abdulcebbar-Şerif Murteza)
}

\author{
NIYAZI KAHVECI \\ Dr. \\ e-mail: kahvecitl@yahoo.com
}

\begin{abstract}
The Polemics Between the Shi'a And the Mu'tazilah on the Ghaybah (al-Qâdî Abd al-Jabbâr and al-Shariff al-Murtadâ) The belief of the Ghaybah in the İmamite Shi'a is not only one of the basics of the credo, but also is the essential principle of the total structure of the religion. After the concealement of the twelfth Imam Muhammad b. al-Hasan al-Askerî in 256/ 874, which the Imâmites named this period as the Small Occultation (al-Ghaybay al-Sughrâ), they managed to handle this intercession period by creating the "Proxy/Deputy of the Imam" system. When the last Proxy/Deputy died in 329/941, and the prolonged occultation of the Imam caused disappointment and despaire for the public, the Imâmite had entered into a new era which the ulama had to sort this problem out.

The Shi'ite ulama, by creating a new formulation for the legitimization of the concealement, they named this advent period as the Great Occultation (al-Ghaybah al-Kubrâ), and transferred the Hidden Imam into Promised Mahdi, who one day, when God permites, will return and fill the globe with justice and equity. This doctrinal evolution, created the Ghaybah literature. The success of the ulamâ in legitimazing Imam's Ghaybah, and creation of such literature, provided them to obtain the authority of the Hidden Imam to be named as the Walayât al-Fakîh.

The opponents of Shi'a had refuted the belief of Ghaybah. The Shi'ites responded them and whemently defended this belief. Consequently, a vast polemic literature of "Refutation (Raddiya)" has come into being. One of them occurred between the Mu'tezilite great mutakallîm-scholar alQâdî 'Abd al-Jabbar (d. 415/1020) and his disciple Imamite mutakallîm-scholar al-Sharîf alMurtadâ (d. 436/1044). In his time the responsibility of defending the Imâmite doctrine of Ghaybah fell on him. He wrote al-Shâfi fi'l Imâmah, in reply to the Mu'tazilite al-Qâdî 'Abd alJabbâr's refutation of the Imâmate in his al-Mughnî fí Abwâb al-Tawhîd wa al-Adl. In al-Shâfí, alMurtadâ deals with the question of ghaybah within the Imâmate. Kâdî's critisizm of ghaybah rests upon two questions; namely holding the individuals with the religious obligations (al-takliff), and the implementation of the penalties (iqamat al-hudûd) become impossible during the absence of the Imam, as the İmâmites see him vital for these two impositions.
\end{abstract}

\section{key words}

Polemics, Shi'ites, Mu'tazilites, the Hidden Imâm (al-Imâm al-Ghâib), the Occultation (al-Ghaybah)

\section{I- Şia'da Gaybet}

İmamî Şiilik'te Gaib İmam'a inanç, sadece itikadın temel ilkesi değil, aynı zamanda dini yapının esasıdır. ${ }^{1}$ İmamîler'in inancına göre, onbirinci İmam

1 A. Sachedina, "A Treatise on The Occultation of the Twelfth Imamite Imam", Studia Islamica, 1978, MCMLXXVIII, 109-125, 109. 
Muhammed b. Hasan Askeri'nin oğlu onikinci İmam Muhammed el-Mehdi, 260/873-874 y1lında 'adaleti' tesis etmek amaciyla tekrar yeryüzüne dönmek üzere, teknik tabiri ile, gaybet'e girmiştir. Bu tarih, İmamîler için Küçük Gaybet (el-Gaybet es-Suğrâ)'in başlangıcıdır. ${ }^{2}$ Şiilerin rivayetlerine göre Küçük Gaybet dönemindeki imam, aktif siyasi güce sahip olamasa da, sefir ve vekil ünvanı ile dinî-adlî otorite verdiği yakın, güvenilir, alim ve fakih kişilerle, gaybeti halinde gerekli gördüğü kişileri kabul edip görüşmek, mali işleri düzenlemek, özel ve genel müşkilatı çözmek, dört sefirden başkalarını tayin etmek ve Küçük Gaybeti bitirmek gibi işler yaparak sosyal ve dini yapıyı idare ve fikhî otorite icra ediyordu. ${ }^{3}$ "İmamlara niyabet" sistemi, son Vekil'in, 329/941'de ölümüyle sona ermiş ve Büyük Gaybet (el-Gaybet el-Kubrâ), devri başlamıştır. ${ }^{4}$

İmam'ın sağ olup olmadığı daha Küçük Gaybet'in sonunda sorgulanmaya başlanmış ve Şiilerin büyük çoğunluğunun ondan umutlarını kesip Gaib İmam'a inançlarını iptal ettikleri rivayetleri mevcuttur. ${ }^{5}$ Fakat 4/10. asırdaki ulema, İmamların daha önceleri, senedlerini Hz. Ali'ye dayandırdığı gaybet üzerine zaman zaman rivayet ettikleri hadisler/ahbar, sem'î mesned yaparak onikinci İmam'ı ve gaybetini meşrulaştırmış ve bunun asırlar önce yapılan bir İlahi plan sonucu olduğunu, halka inandırmaya çalışmıştır. ${ }^{6}$ Böylece Gaybet, bir süre hadisler/ahbar ile savunulmuştur. Bu usule en iyi örnek, Kuleyni (ö.328/940)'nin el-Kâfi ve İbn Babuya Saduk (ö. 381/991)'un hadis derlemesi olan eserleri gösterilebilir. İlk derlenen ahbar eseri olmasina rağmen Saduk, muhtemelen mevsuk olduklarını ispat amacıyla Kemalu'd-Dîn adlı eserindeki hadislerinin, 256/874'den önce yazılan Usulu'l-Erba'a Mie'de toplandığını iddia eder.?

Onuncu asrın sonuna varıldığında bu hadislerin, diğer bir ifade ile sem'in, gaybetin inandırıcılığı için yetersiz kaldığı anlaşılmıştır. Bu nedenle İmami ulema, Kelamî tartışmalara baş vurmuştur. Aynı konuların, aklî-kelamî usulle ictihad yaparak tartışılması, aynı zamanda ahbar ravisi olan Şii alim Mufid

2 Muhammed Husayn Tabâtabâ'î, Shi'ite Islam Albany, 1975, s. 210; E. R. Fı̆̆lalı, Çağımızda İtikâdî İslam Mezhepleri, İstanbul, 1980, s. 112; Mustafa Öz, İmamiyye Şiasında Onikinci İmam ve Mehdi İnancı, İstanbul, 1995, s. 48; Avni İlhan, Mehdilik, İzmir, 1976, s. 72.

3 Muhammed es-Sadr, Târîhu'l-Gaybeti's-Suğrâ, Beyrut, 1972, s. 566-630.

469 sene süren ve 329/941'e kadar süren Küçük Gaybet süresince dört adet vekil/sefir tayin edilmiştir. Sefirlerin isimleri için bkz. Muhammed es-Sadr, Târîhu'l-Gaybeti's-Suğrâ, Beyrut, 1972, s. 396 vd.; Fı̆̆lalı, Mezhepler, s. 112-113; M. Öz, İmamiyye, s. 62-68; A. İlhan, Mehdilik, s. 72.

5 Muhammed b. İbrahim (ö. 970), Kitabu'l Gaybe, Tebriz, 1317/1899, s. 80.

6 İbn Ebî Zeyneb (4/10. asır), Kitabu'l-Gaybe, thk. Ali Ekber el-Ğaffârî, Tahran, 1397, s. 141, 166.

7 Kemalu'd Din, s. 2, 3, 19. Şeyh Saduk, bu eserin müstakil bir babında yüzyıldan daha uzun yaşayan insanları anlatarak Gaib İmam'ın hayatta olduğunu savunmaktadır. 
(ö.1022) tarafından başlatılmıştır. O, imamın gaybetini meşrulaştırabilmek için Kelam usulünü yoğun bir şekilde istihdam etmiştir. Eseri Fusûlu'l Aşere fi'l Gaybe'de Gaib/Gizli İmam'ın varlığını ispat amacıyla iki temele yer vermektedir. Bunlar; her devirde bir imamın mevcudiyetinin gerekliliği ve imamın ismetidir. Mufid, ahbar isnad etmede kullanılan "filan imam dedi" yerine, "onlar şunu derse....biz deriz ki..." şeklinde diyalektik reddiye metodunu kullanmıştır.8 Mufid'in konuyu bu şekilde ele alışı sonraki ulemanın tartışma çerçevesini çizmiştir. ${ }^{9}$ Bu durum, öğrencileri Karacaki (ö. 448/1057) ve Tusi (ö. 458/1067)'de olduğu gibi Şerif Murteza (ö. 436/1045)'da da görülür. ${ }^{10}$

Bu dönemdeki İmamî ulema, onikinci İmam el-Mehdi'nin gaybete girmesini, babası onbirinci İmam Hasan Askerî (845-873)'nin planladığını iddia etmekte ve buna neden olarak, Şiiler'in muhtemel isyanlarına karşı Abbasiler'in, Halife Me'mun ile başlayan katı ve sert politikalarını göstermektedir. Şiilere göre, Halife Mu'temid, İmam Askeri'nin oğlunu arattırıp öldürtmeye çalıştığından Askerî, Onikinci İmam olacak oğlunun doğumunu saklı tutmuş, adını el-Kaim el-Mehdi olarak belirlemiş̧ ${ }^{11}$ ve bu bilgileri sadece bir kaç kişiye açıklamıştır. ${ }^{12}$ Siyaseten olsa gerek Askerî’nin hiç evladı olmadığını savunan alimler de mevcuttur. Mesela İmam Mehdi'nin kendisi ile mektuplaştığ rivayet edilen $^{13}$ Mufid, Askerî, herkesce bilinen bir evlad bırakmadığını söylemiştir. ${ }^{14}$ Şii kaynaklar, Onikinci İmam'ın gaybete girmesine genel olarak üç neden zikretmektedir. Birinci neden; Abbasiler'in, İmamîlere ve İmamlarına karşı takındığı zalimane tavır sonucu bütün Şii imamları göz hapsinde tutmuş ve taraftarları ile temaslarını önlemeye çalışmıştır. ${ }^{15}$ Bu nedenle el-Kaim'in, tekrar zuhur etmeden önce öldürülme korkusu ile gizlendiği kaydedilir. ${ }^{16}$ İkinci neden, Kaim'in zalim yöneticiye itaat etmemeye yemin etmiş olmasıdır. ${ }^{17}$ Kuleyni tarafından

8 Bkz. Muhammed b. Numan el-Mufid, Fusulu'l-Aşere fi'l-Gaybe, Necef, 1951.

9 Jassim Hussain, The Occultation of the Twelfth Imam, Tehran, 1982, s. 145.

10 Şerif Murteza, bu uslübu eş-Şafi fi’l İmame de olduğu gibi, gaybet üzerine yazdığı risalesinde de kullanmıştır. Risale fî Gaybeti'l-Hucce, Resailu'ş-Şerîf el-Murteza, nşr. Es-Seyyid Mehdî erRecâî, Kum, 1405, II, 293. .

11 Muhammed b. Ali Hüseyin Babeveyh es-Sadûk (ö. 991), Kemalu'd-Din ve Tamamu'n-Ni'me, Tahran, 1378/1958, s. 317-323.

12 Saduk, Kemalu'd-Dîn, s. 435; Kuleyni, el-Kafi fi'l-illmi'd-Din, Tahran, 1961, I, 330; Şeyhu'tTaife Ebu Cafer Muhammed b. Hasan et-Tûsî (ö. 460/1067), Kitabu'l-Gaybe, Tahran, 1398, s. $148,152$.

13 Muhammed es-Sadr, Târîhu'l-Gaybeti'l-Kubrâ, Bayrut, 1982, s. 157 vd.

14 el-Mufid, İrșad, Necef, 1972, s. 389-390.

15 Muhammed b. Ali İbn Şehrâşub (ö. 1162), Mealimu'l-Ulema, Tahran, 1353, s. III, 533.

16 el-Mufîd, İlelu'ş Şeria, Necef, 1385/1966, s. 243-244; Kuleyni, Kafi, s. 24.

17 Saduk, Kemal, s. 303, 485. 
zikredilen üçüncü nedene göre gaybet, Allah tarafından mahlukatı bir imtihandır. Gaybet vasitasıyla Allah, Onikinci İmam'ın imametini tasdik edenleri ve etmeyenleri tespit edecektir. Kuleyni gibi diğer ulema, bu gerekçe için çok sayıda ahbar rivayet etmektedirler. ${ }^{18}$

Gaybetin en önemli sonucu olarak, İmamî fukahanın, hem iktidardaki yöneticiler hem de Şii halk üzerindeki otoritesinin genişlemesi zikredilebilir. Vikale idaresinin 329/941 yılında sona ermesi ile İmamîlerin liderliği meselesinde doğan büyük boşluk, İmamî fukahanın kendi faaliyetlerini genişletmelerine ortam doğurmuştur. Genişleyen etkinliği sayesinde fukaha, İmamî toplumun birliğine büyük katkı sağlamıştır. Her imamın vefatını müteakip pek çok fırkaya bölünen İmamîler, fukaha etrafında birleşmişlerdir. Fakihin vefatı, bölünmeye neden olmadığından onun ölümü üzerine bir başkasının liderliğinin kabul edilmesi kolay oluyordu. Böylece Askeri'nin ölümü ile doğan on dört Şii fraksiyon ortadan kaybolmuş, sadece Gaib İmam'ın imametini savunan İmamiyye ayakta kalmıştır. Cemaatlerinin parçalanıp dağılmasını önleyebilmek için bir lidere ihtiyaç bulunduğunu gören fukaha, kendi siyasi otoritelerini tesis etme konusunda birleşmişlerdir. Ulemayı birleştiren kuvvet, Gaib İmam'ın imametine olan inançları olduğundan onlar, zuhuruna kadar Onun diri olduğunda icma ettiler. ${ }^{19}$ Böylece sıradan İmamîlerin,onuncu asrın son çeyreğine kadar, fukaha fetvalarını onikinci İmam'ın gerçek fetvaları olarak görmeleri meselesi hallolmuştu. Fakat kendilerini imamlarıyla eşit otoriteye sahip kılmadılar. Ulema, Kaim'in zuhuruna kadar imamın makamına kimsenin sahip olamayacağından ve humus vergisi imamın payı olduğu için, mükelleflerin, onu bir kenarda biriktirmesi ve Gaib İmam'ın zuhurundan önce ölürse, onu güvendiği kişiye bırakması gerektiğini karara bağlamıştır. ${ }^{20}$

Fakat Gaybet döneminde Şii ulemanın çözmesi gereken en önemli iki mesele; imamın, dini ve ülkeyi koruma ve hadleri infaz gibi görevlerini ifası ve fertlerin mükellefiyeti idi. Gaybet üzerine yazılan eserlerde yapılan Kadı Abdulcebbar $^{21}$ ve Şerif Murteza'nın ${ }^{22}$ tartışmasında, bu meselenin sorulabilecek sorularının ve cevaplarının bir örneğini bulmamız mümkün olacaktır.

18 Kuleyni, el-Kafi, I, 336; İbn Ebî Zeyneb, Kitabu'l-Gaybe, s. 141, 166.

19 Jassim Hussain, a.g.e., s. 152.

20 Şerif Murteza, Fusulu'l Muhtara mine'l Uyun ve'l Mehasin li’l Mufid, Necef, 1966, s. 261.

21 Kadı Abdulcebbar b. Ahmed b. Abdulcebbar b. Ahmed b. Halil b. Abdullah Ebu Hasan Hemedani (325-415/936-1020), Ebu Haşim el-Cubbâî’nin Basra Mutezilesindendir. Devrinin Mutezile şeyhidir. Kadı'l Kudatlık vazifesinde bulunmuştur. Fıkıhta Şafii Mezhebi'ne mensuptur. Buveyhiler'den Sahib b. Abbad tarafından Rey ve Kazvin şehirlerinin Kadılık görevi verilmiştir. Çok sayıda eser yazmıştır. Bkz. Ebu Sa'd Muhassin b. Muhammed el-Cuşemî, Şerhu'l-'Uyûn, 


\section{II- Şia'da Gaybet Eserleri}

Gaybet eserlerinin ehemmiyeti, imamın gaybeti esnasında insanların siyasi olarak nasıl davranacağı ve dinini nasıl ifa edeceği meselesinde yatıyordu. Bu meseleyi çözmesi gereken Şii ulema çok zor bir mükellefiyet ve vazife ile karşı karşıya kalmıştı. Bu yeni meseleyi çözmeye, Ahbar'dan müteşekkil nass yetersiz kaldığından ulema, İslam'a giren felsefe ve mantık sayesinde akla daha çok dayanmak zorunda kalmıştır.

Gaybet kavramı oluşturmak ve eserlerini yazmak Şii ulemaya, halk üzerinde Gaib İmam otoritesini sağlayan "Velâyet-i Fakih" "Mutlak Merce-i Taklîd" yetkisini kazandırmıştır. ${ }^{23}$ Şii ulema çok sayıda Gaybet Eserleri telif etmiştir. Bu eserler, Gaybet-i Suğrâ (260/874)'dan once, Gaybet-i Suğrâ esnasında ve Gaybet-i Kübrâ (329/941'nın başlangıcından sonra olmak üzere üç sınıfa ayrılmaktadır. ${ }^{24}$

\section{Gaybet-i Suğrâ Öncesi}

Ali b. Hasan et-Tâî et-Tatârî (2/8. asır), Kitabu'l-Gaybe. ${ }^{25}$

İbrahim b. Salih b. Enmâtî, Kitabu'l-Gaybe. ${ }^{26}$

Hasan b. Ali b. Faddal (ö. 224//839), Kitabu'l-Gaybe. ${ }^{27}$

Ebu Said Abbâd b. Yakub el-Asfarî (ö. 250/864), Kitabu Ebi Said elAsfârî. ${ }^{28}$

Fadlu'l-i'tizâl ve Tabakâtu'l-Mutezile, Thk. Fuad Seyyid, Tunus, 1986, s. 365-368; Ahmed b. Yahya İbnu'l-Murteza, Kitabu Tabakâtu'l-Mutezile, Beyrut, 1961, Thk. Susanna Diwald Wilzer, 112-3; İbnu'l Esîr, el-Lubâb fì Tehzîbi'l-Ensâb, Misır, 1936, III, 293; Abdulvahhab b. Ali (Tacuddin) Subki, Tabakatu'ş-Şafi'iyyi'l-Kübra Mısır, 1906, III, 219; Yakut el-Hamevi, Mu'cemu'lBuldan, Misir, 1357/1906, 1/245.

22 Şerif Murteza, Ebu Kasım Ali b. Hüseyin el-Musavi b. Musa b. Hüseyin b. Ali b. Ebi Talib, 355/ 966'da Bağdat'ta doğmuş ve yine orada 436/1044'de vefat etmiştir. Kadı Abdulcebbar'ın talebesi ve devrinin Şi'a şeyhidir. İbnu'l Esir, el-Kamil, IX, 180; İbnu'l Murteza, Tabakatu'l-Mutezile, 117; Şeyhu't-Taife Ebu Cafer Muhammed b. Hasan b. Ali Tusi (385-460), el-Fihrist (Calcutta, s. $1853-55$, s. 218; Mustafa b. Hüseyn et-Tefrişi, Nakdu'r-Rical, Tahran, 1900, s. 232-233; Seyyid Hasan Sadr, Tesisu'ş-Şi'a li-'Ulumi'l-İslam (y.y. 1951), s. 214; C. Brockelman, EI2, VII, 634; Zehebî, Tarihu'l-İslam, H. 436 yılı olayları; Ebu Ferec Abdurrahman b. Ali Cevzi, elMuntazam, fi Tarihi'l-Muluk ve'l-Umem Beyrut, 1412/1992, s. XV, s. 294. Çalışmamızda, Kadı'nın el-Muğnî fi Ebvâbi't-Tevhîd ve'l-'Adl, thk Abdulhalim Mahmud ve Süleyman Dünya ve Şerif Murteza'nın eş-Şâfî fi'l-İmâme, Thk. talk. S. Abduzzahir Hüseyin el-Hatib, Tahran, 1986, nüshasını kullandık.

23 M. Saffet Sarıkaya, İslam Düşünce Tarihinde Mezhepler, İsparta, 2003, s. 181-182.

24 Bkz. M. Öz, İmamiyye Şiası, s. 13-20.

25 M. Öz, a.g.e, s. 14.

26 Ebu Abbas Ahmed b. Ali en-Necâş̂i, Ricâlu’n Necâş̂̂, Beyrut, 1408/1988, I, 86.

27 Necaşi, Rical, I, 132.

28 Mustafa Öz, İmamiyye Şiası, s. 14. 
Ali b. Mehzeyâr el-Ehvâzî, Kitâbu'l-Kaim, Kitabu'l-Melâhim. ${ }^{29}$

Fadl b. Şazân en-Nisâbûrî (ö. 263/873), el-Gaybe. ${ }^{30}$

İbrahim b. İshak el-Ahmerî en-Nihavendî. (ö. 269/879), Kitabu'l-Gaybe. ${ }^{31}$

Hasan b. Muhammed b. Süma'a (ö. 263/877), Kitabu'l-Gaybe. ${ }^{32}$

Gaybet-i Suğrâ Esnası

Abdullah b. Cafer el-Himyeri (ö. 293/905), el-Gaybe ve'l-Hayre. ${ }^{33}$

Selame b. Muhammed b. Ebi'l-İkram (ö. 340/950 civar1), Kitabu'l-Gaybe. ${ }^{34}$

\section{Ali b. Hasan el-Curmî, el-Gaybe. ${ }^{35}$}

Hasan b. Ali el-Betâinî, Kitabu'l-Gaybe. ${ }^{36}$

Muhammed b. Kasım Ebu Bekir Bağdâdî, el-Gaybe. ${ }^{37}$

Muhammed b. Yakub el-Küleynî (ö. 329/940), el-Kâfi. ${ }^{38}$

İbn Bâbeveyh el-Kummî (ö. 329/940), el-İmame ve't-Tabstra Mine'l-Hay$r e . .^{39}$

\section{Gaybet-i Kübrâ Başlangıcı Sonrası}

Hasan b. Hamza el-Mer'aşî (ö. 350/960 civarı), Kitab fi'l-Gaybe, Kitabu'lEşfiye fì Me'âni'l-Gaybe. ${ }^{40}$

Muhammed b. Ahmed b. Mehran el-Cemal (ö. 358/968), Kitabu'l-Gaybe ve Kesfi'l-Hayre. ${ }^{41}$

Hasan b. Muhammed, İbn Ehi Tâhir (ö. 358/968), Kitabu'l-Gaybe. ${ }^{42}$

Muhammed b. İbrahim b. Cafer el-Katib en-Nu'mânî. (ö. 360/971), Kitabu'l-Gaybe. ${ }^{43}$

İbn Ebu Zeyneb en-Numânî (ö.360/971), Kitabu'l-Gaybe. ${ }^{44}$

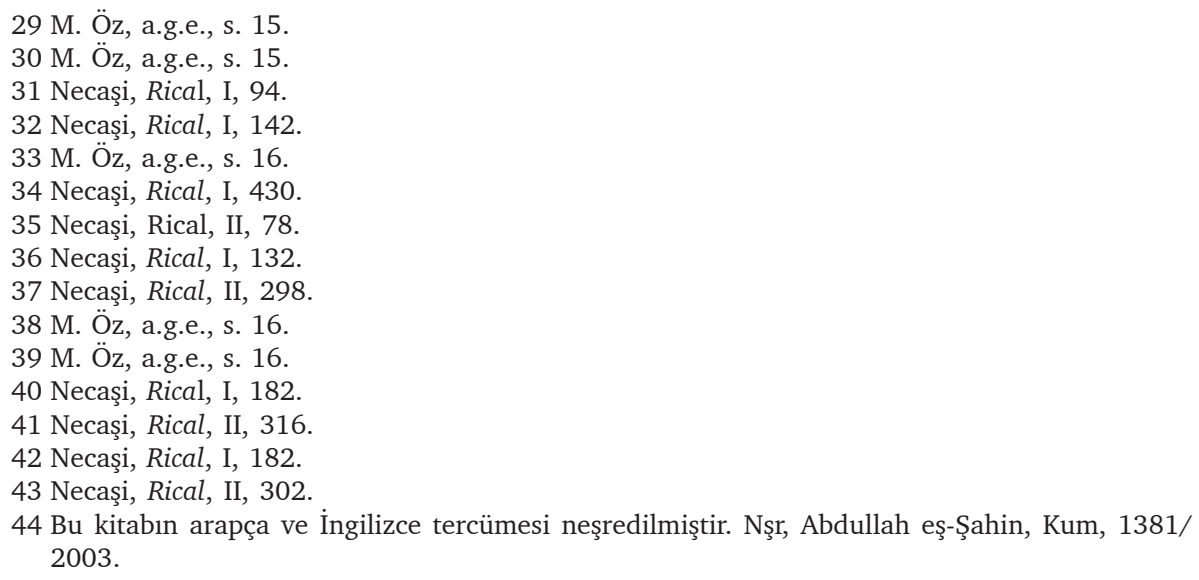


İbn Babeveyh el-KummîŞeyh Sadûk (ö. 381/991), er-Risaletu'l-Evvele fi'l-Gaybe,Kemalu'd-Din ve Temamu'n-Ni'me. ${ }^{45}$

el-Mufîd, Muhammed b. Muhammed b. Numan (ö. 413/1022), Kitab Cevâbâti'l-Fârıkîn fi'l-Gaybe, Kitab Fi'l-Gaybe. ${ }^{46}$

Hasan b. Ali el-Vezîr (ö. 418/1026), el-Gaybe. ${ }^{47}$

Şerif Murteza (ö. 436/1044), el-Mukni' fi'l-Gaybe. ${ }^{48}$

Muhammed b. Ali Karacaki (ö. 448/1057), Burhan ala Sihhati Tûli'lÖmri'l-İmam Sahibi'z-Zamân. ${ }^{49}$

Muhammed b. Hasan Tusi (ö. 458/1067), el-Gaybe.

\section{III- Gaybet Doktrini}

Şia'nın gaybet doktrinini ortaya koyması bakımından, Şerif Murteza'nın, "Risale fi Ğaybeti'l-Hucce" isimli risalesini özetlemeyi faydalı görüyoruz. ${ }^{50}$

1. Gaybet, esasların fer'idir. Zor olan, bu esasların sahihliğidir. Bunların sihhati ispat edilmezse, gaybet üzerine kelam zordur.

2. Bu esaslar, her zamanda bir reisin bulunması ve onun masum olmas1nın kaçınılmazlığıdır. Akıl, bunları iktiza eder.

Her zamanda imamın vucubiyetine delili, insanların imamın varlığında husun fiili işlemesine ve kubuh fiili terkiine ve insanlar arasında zulmün giderilmesine neden olması ve yokluğunda bunların tersinin vukua gelmesidir. İmamın ismetinin vucubiyetinin delili, imama ihtiyaç kadar onun ismetine de gereklilik olmasıdır. İmamın masum olmaması, sayısız miktarda imamı iktiza eder.

3. Gaybete sebep, zalimlerin, imamı korkutması, onun vazifelerini icrasını ve mütemekkin olmasını engellemesidir. Kendisi ile amaçları arasına engel konursa, imameti icra etme farzı ondan sakıt olur. Zalimler nedeniyle canından korkarsa, gaybeti vacip olur; zarardan kaçınmak, aklen ve sem'an vaciptir.

4. Gaybetin, süresinin uzun veya kısa oluşu değil, illet ve sebebinin süresi önemlidir.

5. Gaib imamın, seleflerinden farkı, o kılıcı ile gelecek, halkı kendisine taate çağıracak, muhaliflerine karşı cihad ederek zalimleri ortadan kaldıracaktır.

45 Necaşi, Rical, II, 311; M. Öz, a.g.e., s. 18.

46 Necaşi, Rical, II, 327-331.

47 Necaşi, Rical, I, 191.

48 Necaşi, Rical, II, 102-104.

49 Bkz. Meclisi, Biharu'l Envar, Tahran, 1395, LI, 300-301.

50 Risale, Seyyid Mehdi er-Ricâlî tarafından Resailu'ş-Şerîf el-Murteza, Kum, 1405 isimli kitapta neşredilmiştir. 
6. Gaybetteki imamın dostları ve onun imametine kail olanlar, gaybetinde bile ondan menfaat sağlayacaklardır; aralarında onun vücudiyetine inanmakla ve onun cezalandırmasından korkmakla kubuh işlemeyecek ve husun ifa edeceklerdir. İmamdan bu menfaatlenme onların mükellef olmasinı sürdürür.

7. Gaybet halinde hadlerin infazı meselesi: Suçu işleyen kişi ölmeden, imam zuhur ederse, haddi infaz eder. İmam zuhur etmeden suçlu ölürse, bunun günahı, imamı korkutup gaybete zorlayanlarındır. Bu, hudud ikamesi meselesinde şeriatın neshi değildir; çünkü hudud ikamesinin farzı nesh edilmemektedir.

\section{IV- Kadı Abdulcebbar-Şerif Murteza Tartışması}

Şia ile Mutezile, birbiri ile en çok tartı̧̧an ve birbirini en çok etkileyen mezhepler sayılmaktadır. Mutezile, Zeydiye Şiası'ndan imamın 'tafdili' prensibini alarak Ali'yi efdal görmüştür. Mutezile, İmamiyye Şia'sının akaidinden bir şey almamıştır. ${ }^{51}$ İmamet, İmamiyye indinde usul-i dinin dördüncü esasıdır. Ehemmiyeti nedeniyle, nübüvvet ile mukarindir. Bu esas, İmamiyyeyi, diğer mezheplerden ve Mutezile'den ayıran itikadî kaidedir. Bu, Şia'nın, Mutezile ile en çok tartıştığ 1 meseledir. Şia ile Mutezile arasındaki yazılı tartışmaların başlama zamanını kesin olarak tespit etmek zordur. Fakat, mezheplerin reddiye eserleri üzerinde yaptığımız çalışma bize şunu göstermektedir: Zeyd b. Ali (ö. 122/740), mezhep ismi zikretmeden Mutezili Vasil b. Ata (ö. 131/749)'ya red içeren bir risale yazmıştır. ${ }^{52}$ Şia, isim zikrederek Mutezile'ye karşı ilk reddiyeyi, Hişam b. Hakem (ö. 199/816) ile yazmıştır. ${ }^{53}$ Bu tarihler esas alınacak olursa, Şiilerle Mutezilîler arasındaki ilk yazılı tartışmaların, ikinci/sekizinci asrın ilk yarısında başladığı söylenebilir.

Makalemizin konusu, özellikle beşinci/onbirinci asırda Şia-Mutezile arasındaki nadir tartışmalardandır. Kadı Abdulcebbar, Mutezile'nin, silinmeye yüz tuttuğu bir asırda, diğer mezheplerle tartışmaya girebilen mezhebin nadir yetişen büyük alimlerindendir. Ayrıca bu devrede Kadı, Mutezile'yi bitirmeyi amaçlayan Eş'ariliğe ve Şia'ya karşı direnmeye çalışmıştır. Şia, bu devrede, Mutezile'nin silahlarını çokca kullanmıştır. Bu nedenle, Murteza, imamın gaybetini, hocası Kadı'nın ve Mutezile'nin usulü ile ispat etmeye çalışmaktadır. Bu çalışmamız, Kadı ile Murteza'nın usuldeki bazı benzerlik ve farklılıklarını ortaya koyacak olması bakımından da önemlidir. Bu tartışma,

51 Abdullatif Abdulkadir Hifzî, Te'siru'l Mu'tezile fi'l Havâric ve'ş-Şia, Cidde, 1461/2000, s. 467.

52 Fuat Sezgin,Geshichte Des Arabischen Schrifttums (Kisaca GAS) Leiden, 1967, I, 590

53 İbn Nedim, el-Fihrist, s. 308; Tusi, el-Fihrist, s. 22258; Necaşi, Rical, II, 397. 
aynı zamanda, Büyük Gaybet (329/941)'in ve Büveyhîler (334-447/9451055)'den Sahib b. Abbad (344-367/955-977)'nn, teşeyyü' ve i'tizali birleştirme teşebbüslerinin akabinde vuku bulmuş olmasından dolayı ayrıca önem taşımaktadır.

Müfid (ö. 413) ve Ebu Cafer Tusî (ö. 460)'nin dahil olduğu muteahhir Şii ulema gibi, Şerif Murteza, usulde, Mutezile'den etkilenmiş ${ }^{54}$ ve İtizalî-aklî metodu, İmamiyye'de kullanan ilk kişi sayılan Mufid'in silsilesini takib etmiştir. Şerif Murteza, İmamiye tarafından bu usulün onbirinci asırdaki temsilcisi görülmektedir. ${ }^{55} \mathrm{O}$, Tusînin uslübu olan ahbar ile birlikte teolojik tartışma yerine, Mufid'in diyalog kalıbını benimseyerek gaybet meselesini aklî delil, istidlaller ve Kelam metodu ile geleneksel ahbar uslübunu beraber kullanmaktadır.

Kendisinden sonraki asırlarda Mutezile'nin referansı kabul edilen Kadı Abdulcebbar (ö. 415/1020), Şerif Murteza (ö. 436/1044)'nın hocası olmasına rağmen, ikisinin hem mezhebi hem de imamet konusundaki fikirleri tamamen farklıdır. İmamet meselesinde bazı teferruat hariç, Ehl-i Sünnet ile aynı fikirlere sahip olan Kadı, imameti şöyle görür: İmamet, akıl ile değil, sem' ile sabittir. Şeriatı bilmek için imama ihtiyaç yoktur; çünkü ona, hadleri ikame, ülkenin sınırlarını muhafaza etmek ve ordular düzenlemek, şeriatın ahkamını tenfiz gibi sem'î işler için ihtiyaç vardır. ${ }^{56}$ Murteza'ya göre imam, mükellefler için beyan menzilesinde ve Allah'ın insanlara bir lutfu olduğu için zamanın, Hüccet'ten hali olması sahih değildir. Böylece imam, insanları salaha yaklaştırır ve fesattan uzaklaştırır. Bu fonksiyonu görebilmesi için imamın, masum olması vacibtir. ${ }^{57}$

Kadı Abdulcebbar, el-Muğnî adlı eserinde gaybet üzerine müstakil bir başlık açmamıştır. Şia'nın imamet fikriyatı ile irtibat kurduğu yerlerde İmamın gaybetine temas etmiş ve yukarıda özetlediğimiz İmamiyye'nin gaybet teorisini, son iki maddesi olan teklifler ve hadlerin infazı meselelerini ele alarak çürütmeye çalışmaktadır.

a- Teklifler

Kadı Abdulcebbar, imametin aklen vacip olduğunu çürütmeye dair açttğg 1 faslın, "şüpheler" bölümünde imamın gaybetini ele almıştır. ${ }^{58}$ İnsanların

54 Hifzî, Te'sîru'l Mu'tezile, s. 465.

55 Bkz. Meclisi, Bihar, LIII, 181.

56 Bkz. Kadı Abdulcebbar, el-Muğnî, 20, I, 41 ve Serhu Usûli’l Hamse, tlk. Ahmed b. Hüseyin b. Ebi Haşim, thk. Abdulkerim Osman, Kahire, 1965, s. 751.

57 Murteza, Cumelu'l 'ìlm ve'l Amel, Necef, 1387, s. 42-43; Şerif Murteza, eş-Şâfí fi'l-İmame.

58 Kadı Abdulcebbar, el-Muğni, 20, I, 17. 
sahip olduğu; şehvet ve hevaya düşkünlük, şüphe etme, sehv ve galat gibi noksanlarını izale için masum imama ihtiyaç duyulmasını, imamın varlığına aklen vacib yapan Şi'anın delilinden hareket ederek gaybet tezinin geçersizliğini şöyle savunmaktadır: "Her devirde, her belde ve toplumda imam ve hüccetin bulunması, yukarıda zikredilen noksanlıkları bulunduğundan mükelleflere Allah'ın tekliflerinin sahihliği için lazım olması durumunda, insanların bu noksanlıklarını izalesi, imamın şahsının varlığı ile değil, ondan zahir olan ve öğrenilen bilgi ile mümkündür. Aksi durum, bu zamanda ve zamanların çoğunda mükelleflerin, mazur ve üzerlerinden teklifin sakıt olmasını onlara (İmamîler'e) vacib yapar. Teklif, imamın varlığına bağlanırsa gaybet durumunda mükellefler, dini mükellefiyetlerden muaf olurlar ki bu iki durumdan her birini irtikab, dinden çıkma nedenidir. Bu fikrimizin hilafını tecviz ederlerse, kendi sözlerini nakzetmiş olurlar." ${ }^{59}$ Murteza, bu iddiayı şöyle cevaplamaktadır: "İmamın zahir olmaması, mükellefin ondan menfaat sağlamadığı anlamına gelmediğinden onun zuhur etmemesindeki hal ile aynının/şahsının ademindeki hali, bu açıdan aynı değildir. Bu nedenle mükellefler, görevlerini ifa etmekle yükümlüdür. İmamın gaybeti, insanların mükellef olmalarına mani değildir; çünkü zalimlerin korkutması nedeniyle mükellefler onu gaybete ve istitara ihtiyaç duyurttuklarından dolayı imam zuhur etmeyince onunla vaki olan maslahatın fevtinde hüccet, mükellefler üzerine olur. Böylece imamdan faydalanmayı kendilerini men edenler, yine mükelleflerin kendileri olmaktadır." ${ }^{60}$ Murteza, bu fikrin zıddını şöyle ifade eder: İmamın şahsının ademinden (yani ölümünden) dolayı mükellefler, ondan yararlanmaktan mahrum kalırsa hüccet, bu yararlanmayı kaybettirene olur ki bu Zat, Allah'tır. Mükelleflerin mazur olma gibi illeti, bertaraf etmesi Allah'a vacip olduğunda, imamın vücudunun, ona taat ve boyun eğme emrinin kaçınılmazlığını biliriz. ${ }^{61}$

Metnin insicamından Murteza'nın "mükellefler" tabirinden kasdının, sadece İmamîler'in değil, aynı zamanda Abbasi Halifeleri'nin de olduğunu takip eden şu ibare ifade etmektedir: "İmamı, zuhurdan ve imamet görevini ikameden men eden mükellefin ve birileri tarafından namaz teklifinden alıkonan kimsenin hali, onu ikameye kendi filleri ve gücü ile ulaşamayan kişinin hali gibi değildir. İmam'ın bu gaybete girmede bir dahli bulunmadığından kendisi sorumlu tutulamayacaktır. Zalimler ve imamı korkutanlar, onun korkusunu ve gaybetine ihtiyaç duyuran şeyi izaleye kadir ve müte- 
mekkindir."62 Murteza'nın, Abbasi Halifelerini, imamın gaybetinden sorumlu tuttuğunu, dolayısıyla günahkar gördüğünü söyleyebiliriz. Burada onlara, imamın zuhuruna engelleri ortadan kaldırmaları için de bir çağrı bulundu$\breve{g} u$ intibainı edinebiliriz.

Murteza, imamın gaybetinin nedenini, zuhuru durumunda bazı mükelleflerin ya da çoğunun ifsatta bulunacaklarını, hallerinden Allah'ın bilmesine bağlamayı caiz görmez. İllet olarak imamın zuhuru, fesada müessir kabul edilirse, imametin aslının; vacibatın ifası ve mukebbehatın irtifaında lutuf olmasına avlettiği şeyin sukutunun vacib olacağ $1 n 1^{63}$ göstererek, tamamen İmamî-teolojik bir gerekçe ileri sürmüştür. Murteza'nın bu kelamı$\mathrm{n} ı$ şu tarihi durumla irtibatlandırmak mümkündür: İmamın zuhur etmesi ile, taraftarlarının (Alevi/İmamîler) mevcut idareye isyan gibi mefsedet çıkarmaları büyük bir ihtimaldir. Hatta İmamiye teorisine göre İmam'ın zuhuru, adil düzeni kurmak için dönüşü demektir. Bu dönüşte iktidar, ihtilalle ele geçirilecektir ki insan kanı akması kaçınılmaz olacaktır. Akıllara böyle bir soru geleceği ihtimaline dayanarak olsa gerek Murteza, İmam'in zuhurunun fesada neden olacağını reddetmektedir. Kendi izah ettiği gibi, böyle bir etkisinin vuku bulacağını kabul etmek, teorileri ile tezata düşmek demektir ve onunla bağdaştırıcı izahı güç olacaktır. Böylece Murteza, çok zor bir durumu izahı başardığını düşünmektedir.

İmamın zuhurunu men eden illet, o zuhur edince zalimler, üzerine gidip onu öldüreceklerini ve kanını akıtacaklarını Allah'ın ona bildirmesidir. Zuhuruna mani, bundan başka bir şey değildir. Zarardan mücerred korku ve nefsi telef etmeye ulaşmayan zarar ve benzerleri, gaybet için yeterli değildir. ${ }^{64}$ Murteza, imamın can güvenliğinin kesin şekilde tehdit altında bulunduğunu Allah'ın bildirmesine dayandırarak gaybeti, sem'î ve aklî olarak meşrulaştırmaktadır. Murteza'ya göre, on ikinci İmam, sadece Abbasi otoritelerinden değil, aynı zamanda taraftarlarından da gizlenmiştir. Bu, önceki imamların saklanma nedenlerinden farklıdır. Murteza gibi aynı devrin İmamî ulemasının, önceki imamların gizlenme nedenleri yerine onikinci İmam'ın zuhur etmeme gerekçeleri üzerinde durmaları gibi bir önemli uslûb farklılığından söz edilebilir. ${ }^{65}$ Murteza'nın, İmam zuhur ettiği zaman zalimlerin onu öldüreceğini “Allah'ın, ona bildirmesi”ni kaydetmesi, bu durumun vuku bulacağını daha önceden bildiren bir hadis/habere telmihtir. Küleyni'nin rivayet ettiği bu haberde, "İmam'ın ismini taraftarlar1na söylersen, onlar bu bilgileri toplumda ifşa edeceklerdir. Onlar (Abbasi-

62 Şerif Murteza, eş-Şafi, I, 146.

63 Şerif Murteza, eş-Şafi, I, 146.

64 Şerif Murteza, eș-Şafi, I, 146.

65 Bkz. Kuleyni, el-Kafi, I, 328-330. 
ler), yerini bilirlerse onu öldüreceklerdir," denmektedir. ${ }^{66}$ Önceki imamlar, taraftarları tarafından gizlendikleri yeri ve faaliyetlerini düşmanlarına ifşa etmeleri nedeniyle biri 70/689, diğeri 140/757 yıllarında iktidarı ele geçirmek için yaptıkları isyanları akamete uğramış ve imamlar tutuklanmışlardı. ${ }^{67}$ Murteza'nın bu tarihi olaylara telmih yaptığını söyleyebiliriz. Dostlarına görünmemesinin nedeni, kendisinin haberini yaymalarından korkmasıdır; onlar, onun zikrini yaparlar, düşmanları bunu duyar ve üzerine giderler. Bu durum, düşmanlarından istitara mucib dereceye tevil edilir. ${ }^{68}$

Murteza, Gaib İmam'ın bütün bu can güvenliğine rağmen, bazı dostlarına ve şiasına zuhur etmeyeceğini düşünmelerinin kat'i olmadığını söylemektedir. Bu, bilakis caizdir. Onlardan hiç birine zahir olmaması da caizdir. "Ama hepimiz, onun hal-i nefsini biliriz," demektedir. Bütün insanlar1na veya bazılarına zuhur etmemesinin sebebi olarak yine can güvenliği illetini ileri sürmektedir. ${ }^{69}$ Bu çözümleme ile Murteza'nın, imamlara otorite sahibi olmaya devam etme imkanı sağlamaya çalıştığı söylenebilir. Tabi ki bu çaba, Şii ulemanın işine yaramaktadır. Çünkü imamların yokluğunda, onların yetki ve fonksiyonlarını ulema deruhte etmektedir. Nitekim, gaybetin uzun sürmesi nedeniyle Murteza devrindeki ulemanın geliştirdiği velayet-i fakih müessesesi, Şii dünyada ulemanın siyasi iktidarını sağlamıştır.

Kadı'nın, "Görünmekten mani sebep, öldürülme olunca, öldürüleceği bilinen her imam ve nebi'ye görünmesini tahzir ve gaybetini Allah'ın vacib yapması gerekli olur. Öldürüleceğini bildiği hüccetlerinden bazılarına zuhuru, Allah'ın mübah yapması caiz olursa, aynısı bütün imamlar hakkında da caiz olur. Böylece zikrettiğiniz illetin, zuhura mani olması batıl olur," şeklindeki itirazı, İmamiye'nin gaybet kavramı ile gayet tutarlı görülebilir; çünkü Şi'a imamlarının onbir ve onikincisi hariç, aynı derecede can güvenliği sorunu olmasına rağmen hepsi zuhur etmiştir. Murteza, cevabına "mükelleflerin maslahatını" illet yapmaktadır. Kadı'nın zikrettiği durumun, imamın zuhuruna mani olabilmesi, bu maslahatın, imamın aynı ile zuhur etmekle zarar görmesine bağlıdır. Gaib İmam'ın zuhuruna Allah'ın müsaade etmemesinin nedeni, onun yerine geçecek başka bir hüccetin bulunmadı̆̆g$\mathrm{n} 1$ ve öncekilerin gaybetine müsaade etmemesine sebep ise onların yerine geçebilecek bir başka imamın bulunduğunu Allah'ın bilmesidir. ${ }^{70}$ Dolayısıyla bu son imam, zuhur ederse öldürülecek ve artık tamamen hüccetsiz kalması nedeniyle "mükelleflerin maslahatları" zarar görecektir. Onikinci

66 Kuleyni, el-Kafi, I, 333.

67 Kuleyni, el-Kafí, I, 369.

68 Şerif Murteza, eş-Şafi, I, 148.

69 Şerif Murteza, eș-Şafi, I, 149.

70 Şerif Murteza, eş-Şafi, I, 147. 
İmam'ın aynı zamanda taraftar ve dostlarına zuhur etmekten kaçınmasının nedeni ile düşmanlarından gizlenmesinin illeti ayrıdır. ${ }^{71}$

\section{b) Hadlerin Ikamesi}

Kadı'nın, gaybete taalluk ettirdiği bir başka mesele hudud ve ahkamın infazıdır. Ona göre, bunlar, imamın varlığı durumunda infaz edilir. Şüpheli durumlar ile olduğu gibi, imamın yokluğunda bunlar sakıt olur. "Size göre, bunları ikame edecek görünen imam bulamadığımız zaman durum ne olur sorusuna," ${ }^{2}$ Murteza'nın cevabı şöyledir: İmam, görünmeye ve hadleri ikamesine imkan bulamadığı dönemde hadler sakıt olmaz. Bilakis hudud, suçun failine sabittir. Eğer suçlular, İmam'ın zuhuruna ulaşırlarsa imam, haddi infaz eder; ulaşamazlarsa cezayı infaz, Allah'a kalır; Kıyamet'te dilerse infaz eder veya affeder. Hudud ikamesinin tehiri ve onda bulunan vacibi istimali menden doğan günah, imamı korkutan ve onu istitara ve gaybete zorlayan kişiyedir. Bu duruma kıyasla imam ikame etmemesi Allah'a gerekli olmaz; çünkü Allah, imam ikame etmeyince maslahatın iktiza ettiği hudud, sukut eder ve kendisinde maslahat bulunan bir şeye Allah, kulları için mani olan olur. ${ }^{73}$ Murteza'nın, imamın gaybeti süresince hududu ikame yetkisini, mevdut yönetime ve başka kimseye vermediğinden suçların cezasız bırakılabileceğini söylemek istemektedir. Kadı'ya göre, hudud, ikamesi, imam ikame vucubunun şerîi illetidir. Murteza'ya göre bu görev, imamı ikame için bir gerekçe değildir. En ağır ceza olan hududun, infaz edilmemesi diğer suçların da aynı muameleye tabi tutulacağını gösterir ki bu durumun toplumda kaos doğuracağını söylemek mümkündür.

Kadı, şu tartışmayı yapmaktadır: İmam, görevini yapamazsa Cebrail ya da gökteki diğer meleklerin durumunda olmasına mani nedir? Bu durumda arzda imamdan müstağni olunur; çünkü onlar (Şi’a) nazarında imamın taleb edildiği mana, onun zuhurunu iktiza eder. Zuhur etmeyince imamın varlığı, ademi gibi olur. ${ }^{74}$ Buna cevap olarak Murteza şöyle demektedir: Amaç sadece imamın varlı̆̆ı değil, üstelik onun emir, nehiy ve tasarrufudur; çünkü bu umur ile mükellef, kubuhtan daha uzak ve vacibi fiile daha yakın olur. Fakat zalimler, imamı amacından menettiler. Bundaki kınama onlaradır. Allah, bunu

71 Murteza, bir başka eserinde Onbirinci İmam Hasan Askeri'nin gaybetinin sebebini; istitar ve gaybeti mubih nefse korku olduğunu zikretmektedir. Bkz. Şerif Murteza, Cumel, s. 46.

72 Kadı Abdulcebbar, el-Muğni, 20, I, 74.

73 Şerif Murteza, eş-Şafi, I, 208; Murteza, bir başka eserinde, gaybette Cuma namazının farz olmadı̆̆ını söylemektedir Cuma namazı, Adil İmam'ın bizzat bulunması ilefarz olur. Bkz. Cumel, s. 74; Bayram namazlarını da Cuma namazı şartları ile aynı tutmaktadır. Ibid, s. 76. Bu düşüncede olmasına rağmen İmam bizzat varmış gibi Cuma namazı sıhhatinin şartlarını sıralamaktadır. Ibid, s. 74.

74 Kadı Abdulcebbar, el-Muğni, 20, I, 81. 
zalimlerden taleb edecektir. ${ }^{75}$ İmamın varlı̆̆ı, gizlenmesinden farklı durumdur. İmam, var olup gizli olunca mükelleflere Allah'ın Hücceti sabittir; çünkü mükellefler, onun zuhurunu sağlayan fillere ve onun cihetiyle menfaat ve mesalihe ulaşmaya kadirdir. Bunlar, Cebrail'de yoktur. ${ }^{76}$

\section{Sonuç}

İmamın gaybetine inanmadığından, mezhebinin mebâdiini savunmak değil, Şi'a'nın fikrini çürütmek ve siyaset teorilerinin mühim kıstaslarına göre tezata düştüklerini göstermek amacıyla Kadı, imamın gaybeti halinde doğacak iki meseleye temas etmiştir. 1044'e kadar yaşayan Murteza'nın, metnindeki savunmasında kullandığı tartışmaya gore, gaybetinin üzerinden 170 yıl sonra bile onikinci İmam'ın hala sağ döneceğine inandığ görülmektedir.

Kadı ve Murteza'nın bu tartışmada kullandığı usulü üzerine tespitlerimiz şunlardır: Kadı'nın felsefesi, akla olduğu gibi şeriata/nassa da dayanır. $\mathrm{O}$, şeriatı ve aklı yakîn ifade eden delil olarak görmekte ve ikisini müsavi derecede kullanmakadır. Murteza, istidlal metodu olarak akıl ile nazarı kullanmıştır. Bu metot dairesini, itikadî esaslarını ispat etmeye kadar genişletmiştir. Nakil delilini, sadece bu aklî sonuçları teyid için istihdam etmiştir. Böylece akıl, onun nazarında müstakil bir delil ve dinin usulünde tek merci olmuştur. Akıl, merce olunca, aklî delilleri de kullanması kaçınılmaz olmuştur. Fakat aklı, sadece imamlarını ispat için kullanmıştır. Tevili kullanması durumu, nassları batınî tevillere götürmüştür. İki alim de "Temanu" ve "Mukabele" delillerini çok sık kullanmıştır.

Si'a tarihinde eski bir mesele olan gaybet, son imamın gaybeti ile mehdiliğge dönüşmüştür. Kıyamet kopmadan önce rucu edecek olan ve evrime uğramış bu mehdi-imam fikri sayesinde İmamiyye, doktrinini sürekli öğretme imkanı bulmuş, ümitsizliğe düşmeden mensuplarını ve davalarını canlı ve aktif tutabilmiștir. Murteza'nın, Gaib İmam düşüncesi ile, Şi'a'nın hedeflediği ideal-adil idareyi kurmayı tehir ettiğini ancak, mutlaka bir gün tahakkuku umudunu canlı tuttuğunu söyleyebiliriz. Meşru imamın gaybetinin nedeni olarak sürekli zalimleri zikretmesi, iktidardaki güçleri, Şiiler'in akamete uğrayan hedeflerinin sorumlusu olarak gördüğünü ifade etmek için olabilir. Fakat aynı zamanda gaybetle, zalim siyasi idareyi devirmenin, en azından o zaman için, İmamiler'in mevcut kuvvetlerini aştı̆̆ını kabul ettiği görülmektedir. Bu düşünce ve tavrın en önemli pozitif sonucunun, ulema ile birlikte İmamî toplumun korunması ve Şii düşüncenin reforme edilmesi olduğu söylenebilir. Murteza, imamın gaib olmasının, zahiren varlığından daha etkili olduğunu ifade etmeye çalışmaktadır. Gaybetteki imamın, her an çıkıp geleceği ihtimali, Şii toplumun dağılmaması için psikolojik olarak büyük bir pozitif etki sağlamaktadır. 